\title{
Analysis on the Impact of RMB Exchange Rates on Manufacturing Trade between China and EU Zone
}

\author{
Yimo Wang ${ }^{1, a}$ and Yonghua Yang ${ }^{2, b,{ }^{*}}$ \\ ${ }^{1}$ School of Economics and Management, Yunnan Normal University, Kunming, China \\ 2 School of Economics and Management, Yunnan Normal University, Kunming, China \\ aemail: 798711566@qq.com, bemail: yhyang2003@163.com \\ ${ }^{*}$ Corresponding author
}

Key words: exchange rate, euro zone, manufacturing trade

Abstract: Since the RMB exchange rate regime has reformed for several decades, the exchange rate has been unilaterally increasing steadily and significantly. For long time, Euro zone is one of China's most important trade partners, as a result, import and export between two areas has increased a lot. During this period, the manufacturing import and export accounts a large share. This paper investigates whether the exchange rate between two currencies impact on the manufacturing trade between two countries. According to the situation analysis of the data and empirical analysis on trade econometric model, we find when RMB appreciates, the export from China to Euro market increases significantly, but the import from Euro market back to China shrinks a lot. Therefore, in order to improve trade environment in China, we need to appropriately use the financial instruments, to fully consider the role of euro currency, to change to increasing trade approach, and to improve the production structure.

\section{Introduction}

\section{1 RMB current status}

Before year 2005, RMB policy is Dollar-peg. From year 2005, the policy has changed into a floating system with foundation from supply and demand from the market, and with reference to a basket of currencies. With the second exchange rate reform authorized from Chinese Central Bank in year 2010, RMB has more autonomy and flexibility to fluctuate against other currencies. Because of the irreplaceable status of euro currency, the exchange rate between euro and RMB has significant impact on trade between two areas. From Fig. 1, we find that RMB has been appreciated generally since year 2010. Typically, during the period between March ,2014 and May, 2015, the unilateral appreciation trend is quite obvious. However, during the period between May, 2010 and May, 2011, Chinese RMB has depreciated a lot. After that, Chinese RMB appreciated increasingly and became stable but after March in 2014, RMB depreciated hugely again.

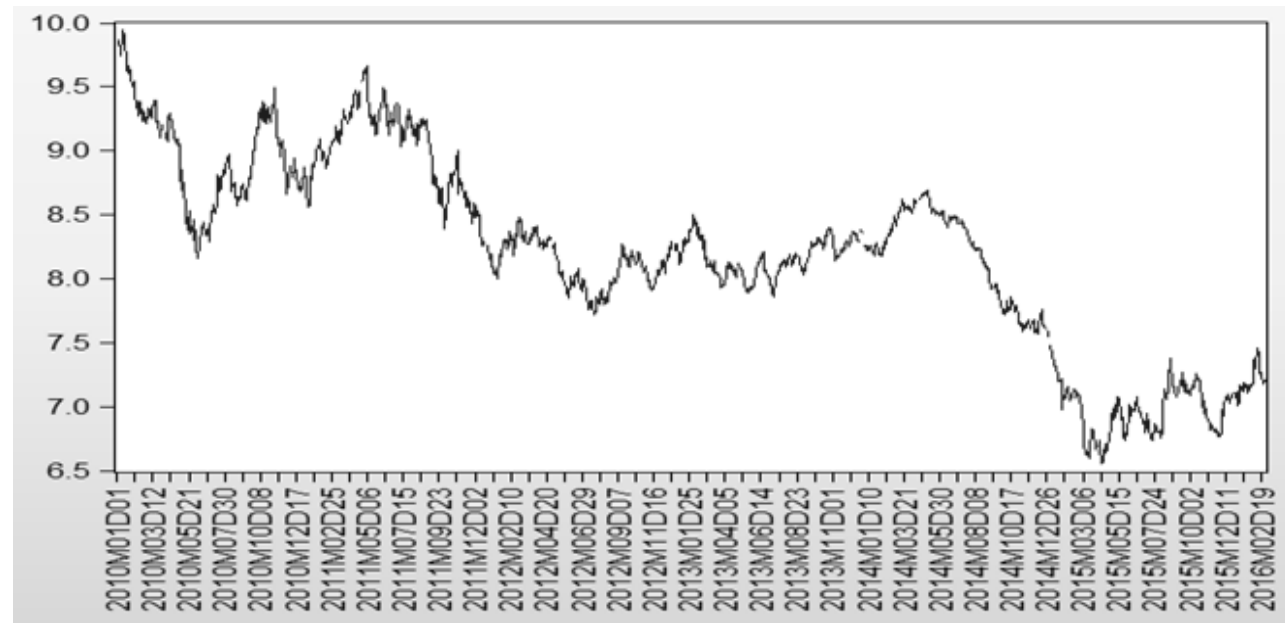

Fig. 1. Exchange rates between Chinese RMB and Euro from 1, Jan,2005 to 26, Feb,2016 


\subsection{Manufacturing trade of between Chinese and Eurozone}

The trade between China and Eurozone has developed rapidly and steadily, and the trade volume has increased year by year. The main products traded between two areas are industrial products. Fig. 2 shows the percentage of China's manufacturing import and export from Eurozone during 2005 to 2015..

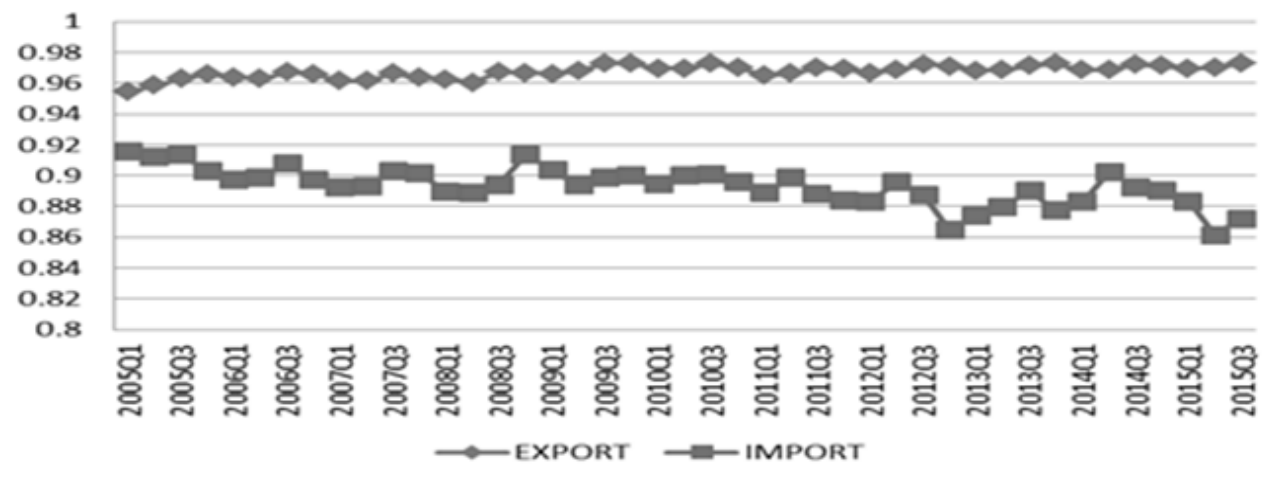

Fig. 2. the percentage of China's manufacturing trade from Eurozone during 2005 to 2015.

From Fig. 2, we can see that China's manufacturing import and export from Eurozone accounts for a great part of the whole trade volume between Chinese and Eurozone. Especially, the manufacturing export accounts for $96 \%-98 \%$ of the total export between China and Eurozone. So as the same for import, the number is around $90 \%$.

\section{The main factors effects of industrial products trade}

There is a series of factors that can influence trade. Among them, the following three factors are the most important.

The first one is exchange rate. According to the normal research so far, there are two kinds of exchange rate effects on the trade in one country. One view is the change of exchange rate will not cast obvious impact on trade in one country. However, the other view thinks that, the short-term fluctuation of the exchange rate has the capacity to increase the total amount of the trade volume in the country. Therefore, for long-term, exchange rate fluctuations can also bring economic stability and sustainable development. As for the impact the exchange rate can bring, many economists believe that, the exchange rate can affect the trade through two ways.

The second one is income level. Income can reflect the economic level and country's development. In general, the higher the national income, the higher the external import demand, so to say the higher the import bill. When the foreign income increases, the foreign import demand will increase as well, which will lead to an increase of domestic export .Due to a large proportion of the total trade in euro area industrial products business, we can say that, when domestic income increases, China's manufacturing import will raise up; while the income of Eurozone increases, domestic manufacturing products, China's manufacturing export will raise.

The third one is price level. Price level is able to reflect the true price of all commodities in a country. When the price level in a country is too high, the demand of the import products will be increased, then the high inflation rate problem will be solved. At the same time, foreign price level also influences domestic import and export. When foreign price level is quite low, the demand of import will be attracted.

\section{Empirical Analysis of the impact of manufactured products trade influenced by the exchange rate between RMB and Euro}

\subsection{Model Design}

According to the international trade theory, we use the imperfect substitute's model from the elasticity approach under the partial equilibrium theory. The specific form is: 


$$
\begin{aligned}
& \ln X_{t}=\alpha_{0}+\alpha_{1} \ln Y_{t}^{*}+\alpha_{2} \ln R E_{t}+a_{t} \\
& \ln M_{t}=\beta_{0}+\beta_{1} \ln Y_{t}+\beta_{2} \ln R E_{t}+a_{t}
\end{aligned}
$$

$\mathrm{Xt}$ is the export volume from China to Eurozone, $\mathrm{Yt}^{*}$ is the income level of Eurozone, $\mathrm{Mt}$ is the import volume from Eurozone, Yt is the income level of China, The Re in this article is real effective exchange rate.

\subsection{Data Selection and Description}

The data used in this paper are all quarterly data from January 2005 to September 2015. There are different kinds of data in the paper, such as import volume and export volume of industrial manufactured products, exchange rate between RMB and Euro.

As for industrial products import and export volume, due to the small proportion of SITC9-unclassified merchandise trade, this paper only selects SITC5-chemical products and related products, SITC6-products classified by raw material, SITC7-machinery and transport equipment and SITC8-miscellaneous manufactured articles as factor variables to investigate. The trade data is from Eurostat, and all data are nominal quartered with adjusted nomination in RMB.

Revenues in China and Eurozone are represented by GDP (Gross Domestic Product) in respective area. Eurozone data is quarter data from Eurostat official website (EUROSTAT). It is quarter data and it is expressed in RMB with a nominal exchange rate adjustment. China's GDP data is from China's National Bureau of Statistics.

All exchange rate data in this paper choose the real effective exchange rate index, which is a weighted average of bilateral exchange rate between RMB and euro. The data can well reflect the relatively comprehensive changes of Chinese Yuan against euro, and all data is from Eurostat official website (EUROSTAT). Real effective exchange rate can eliminate the inflation factor, and it can also take into account of the currency changes from the main business partner country. The increase of the index indicates the appreciation of the domestic currency, while the decrease of the index means the depreciation of the domestic currency. The index can reflect the relative currency value more obviously and more intuitively. At the same time, we adjust different kinds of data by converting them into a set of seasonally data.

\subsection{Empirical results}

The variable set of $\operatorname{LnX}, \mathrm{LnY0}$, and LnRE has co-integration relationship with variable set of LnM, LnY, and LnRE. We can intend there exists long-term equilibrium relationship between two sets. However, in short-run, there might be some errors. Under the Error Correction Model (ECM), we can improve the accuracy of the model so to further investigate the relationship among variables.

We first take the residual errors in the co-integration function as the error correction term, and then we design the error correction model. We get the regression result of the ECM model from Eviews as following.

$$
\begin{aligned}
& \mathrm{D}(\mathrm{LNX})=2.7270 * \mathrm{D}(\mathrm{LNY} 0)+2.4218 * \mathrm{D}(\mathrm{LNRE})-0.008932-0.4516 * \mathrm{ECM} 1(-1) \\
& \text { (2.73) (2.20) (-0.58) (-3.66) } \\
& \mathrm{D}(\mathrm{LNM})=2.0887 * \mathrm{D}(\mathrm{LNY})-0.7602 * \mathrm{D}(\mathrm{LNRE})-0.0408-0.2573 * \mathrm{ECM} 2(-1)
\end{aligned}
$$

From the equations above we can find that, when short-term fluctuation deviates from the long-tern equilibrium, the error correction term adjusts in the opposite direction by 0.4516 and 0.2573 , and then rebalance the term to the equilibrium. From the comparison we get the first model has more powerful adjustment effect, while the second model has relative weaker effect.

Moreover, the coefficients of LnY0, LnRE and LnY, LnRE are all short-term elastic coefficients. The numbers are same as those in the co-integration function. This can also prove that, in the short-term, the effect of the coefficients to explanatory variables has the same effect to that of the long-term. 


\subsection{Empirical results analysis}

Throughout this paper, we mainly use the real effective exchange rate index; therefore, the rising of the index means the appreciation of RMB. From the model above, we can find when real effective exchange rate raises one percent, the industrial manufactured products export will probably raise 2.4218 percent, and import will probably decrease 0.7602 percent. When GDP in Eurozone raises 1 percent, the industrial manufactured products export will increase 2.7270 percent. When GDP in China raises 1 percent, the industrial manufactured products export will increase 2.0887 percent.

In the short term, according to the data analysis, the trade balance between China and Eurozone will deteriorate in the short run. At the beginning, the exchange rate has the "sticky effect". For example, because the related contracts have been already signed, the trade volume will not be influenced by other reasons. However, the real exchange rate has changed, due to the foreign currency denomination, our export income will shrink. At the same time, the import is denominated in home currency, our expenditure cost increases somehow. That will result in an increase of manufactured goods balance of payments deficit, or a decrease of trade surplus.

In the long term, RMB appreciation pressure still exists. Since the exchange rate reform in 2005, $\mathrm{RMB}$ has been appreciating for a long time. Due to the economic environment, the global financial institutions have an expectation of rising RMB. First, the trade surplus in China has been existing for several years, and the foreign exchange reserve, especially the US dollar, keeps growing for a long time. It forces great appreciation pressure for RMB. Secondly, the domestic inflation problem becomes harsh these days. Most economic experts and agent analysts believe that, the appreciation of Chinese RMB can solve the increasing domestic price level. Thirdly, from the financial crisis in 2008, most countries have been using the loose monetary policy to recover their economies. High appreciating pressure is casted by those countries. Therefore, in order to avoid RMB's appreciation, foreign industries import products from China in advance. Finally, the order speed for domestic factories will lower down and the trade surplus will enlarge.

\section{Suggestions}

China should take measures to promote manufacturing trade between China and Eurozone.

Firstly, avoid the exchange rate volatility risk by using the financial instruments.

Secondly, take fully consideration of the Euro status in our currency basket and raise the euro weight to a reasonable level in the basket.

Thirdly, Release the RMB's appreciating pressure, in order to improve the expectation from both domestic and foreign financial institutions.

Fourthly, change the trading growth mode to improve the production structure.

\section{References}

[1] Dornbusch R. Stabilization,Debt and Reform:Policy Analysis for Developing Countries[M].New York:Harvester Wheatsheaf.1993.

[2] Chou W. Exchange rate variability and China's exports [J].Journal of Comparative Economic, 2000(8):61-79.

[3] C.E.Smith.Exchange Rate Variation, Commodity Price Variation and the Implications for International Trade[J].Journal of International Money and Finance,1999,(18):471-491. 